\title{
Observations on Inheritance of Male Sterility in Apricot
}

\author{
L. Burgos ${ }^{1}$ and C.A. Ledbetter \\ Horticultural Crops Research Laboratory, Postharvest Quality and Genetics \\ Unit, Agricultural Research Service, U.S. Department of Agriculture, 2021 \\ South Peach Avenue, Fresno, CA 93727-5951
}

Additional index words. breeding, genetics, pollen sterility, Prunus armeniaca

Male sterility is defined as the deviant condition in normally bisexual plants when no viable pollen is formed (Frankel and Galun, 1977). Male sterility has been exploited as an effective tool to aid hybrid seed production in many crops. Using this trait, seed producers can transform one inbred from a planned hybridization into a "female" line, thereby ensuring seed of hybrid origin on the male-sterile parent (Janick, 1972). However, male sterility is an undesirable characteristic in scion cultivars of Prunus to be used for fruit production because this trait would restrict yield in large monocultural production blocks. From the viewpoint of an apricot breeding program, male sterility is a characteristic to be avoided (Scott and Weinberger, 1944).

A review of apricot (Prunus armeniaca L.) pollen fertility (Burgos, 1991) indicated that only two cases of male-sterile apricot cultivars ('Arrogance' and 'Colorao') have been described (García et al., 1988). In this paper we show where several male-sterile trees were observed in progenies from controlled hybridizations in $P$. armeniaca, and we propose a preliminary inheritance model of the trait.

Nine different crosses with a total of 378 trees were scored for the male sterility trait. Male-sterile anthers can be distinguished visually from normal fertile anthers during the bloom period. Shrunken, discolored anthers are indicative of male-sterile pollen and provide a sharp contrast to the swollen, yellow appearance of normal pollen-fertile anthers (Connors, 1927). Several samples of shrunken, discolored anthers were chosen randomly to

Received for publication 13 May 1993. Accepted for publication 31 Aug. 1993. The cost of publishing this paper was defrayed in part by the payment of page charges. Under postal regulations, this paper therefore must be hereby marked advertisement solely to indicate this fact.

'Dept. of Fruit Breeding, Centro de Edafologia y Biologia Aplicada del Segura, Consejo Superior de Investigaciones Científicas, Aptd. Correos 4195, 30080-Murcia, Spain. desiccate them and examine the pollen. In all cases, the samples with abnormal anthers failed to produce any pollen after they were desiccated.

Crosses made between the selections A90132, K31-110, and K210-35 produced progeny segregating 3 male fertile : 1 male sterile, whereas crosses between any of the above selections and a different parent did not produce male-sterile progeny. An exception to these observations was in the cross K210-35 x K51-71, where two male-sterile trees were identified in a progeny of 140 (Table 1).

These data suggest that A90-132, K31110 , and K210-35 are heterozygous for a recessive male-sterile gene (Msms). These three selections share B67-10 as a common parent. Since all these selections' parents are male fertile, it seems reasonable to think that B6710 is also heterozygous and the donor of the male-sterile allele. All other selections used in this study appear homozygous for male fertility $(M s M s)$. Hence, only crosses between putative heterozygotes yielded a $25 \%$ male-sterile progeny. The two male-sterile trees found in the cross K210-35 x K51-71 could be explained as arising from self-pollinated K21035 flowers that were wrongly collected and planted.

The proposed hypothesis agrees with the Mendelian or "genie male sterility" model described by Frankel and Galun (1977), for which more than 100 cases of male sterility that were detected and analyzed in cultivated plants showed monofactonal recessive inheritance. Also, Scott and Weinberger (1944) established the inheritance of male sterility in peach as a simple recessive. They found three male-sterile and 17 heterozygous peach cultivars.

Further hybridizations will be necessary to confirm the proposed model. Male-sterile individuals need to be back-crossed to both the presumed heterozygous and homozygous dominant male-fertile accessions. Results from these hybridizations will be available only after the 3-year juvenile period is completed.

Hybridizations listed in Table 1 were performed to combine fruit quality attributes. When these crosses were made, the male sterility heterozygous status of the parents was unknown. Since the hybridization of two Msms trees yields $25 \%$ msms individuals, the allelic status of this economically important locus becomes an important factor in the efficiency of an apricot breeding program. The ability to distinguish and rogue male-sterile individuals at the seedling stage would save resources and benefit the apricot breeders by increasing program efficiency. Segregating populations from appropriate hybridizations may provide an opportunity to establish a biochemical or genetic marker linked to this male sterility locus.

\section{Literature Cited}

Burgos, L. 1991. Biologia floral de variedades de albaricoquero (Prunus armeniaca L.). PhD diss., Univ. de Murcia, Murcia, Spain.

Connors, L. 1927. Sterility in peaches. Mere. Hort. Soc. N.Y. 3:215-221.

Frankel, R. and E. Galun. 1977. Monographs on theoretical and applied genetics 2. Pollination mechanisms, reproduction and plant breeding. Springer-Verlag, New York.

Garcia, J, E., J. Egea, L. Egea, and T. Berenguer. 1988. The floral biology of certain apricot cultivars in Murcia. Adv. Hort. Sci, 2:84-87.

Janick, J. 1972. Horticultural science. 2nd ed. W.H. Freeman and Co., San Francisco.

Scott, D.H. and J.H. Weinberger. 1944. Inheritance of pollen sterility in some peach varieties. Proc. Amer. Soc. Hort. Sci. 45:229-232.

Table 1. Number of male-sterile seedlings from various crosses between male-fertile apricot selections.

\begin{tabular}{|c|c|c|c|c|c|c|}
\hline Cross & Total & $\begin{array}{l}\text { Male } \\
\text { fertile }\end{array}$ & $\begin{array}{c}\text { Male } \\
\text { sterile }\end{array}$ & Test ratio & $\chi^{2}$ & $P$ \\
\hline$\overline{\mathrm{K} 210-35 \times \mathrm{A} 90-132}$ & 83 & 65 & 18 & $3: 1$ & 0.48 & $\overline{0.49}$ \\
\hline $\mathrm{K} 31-110 \times \mathrm{K} 210-35$ & 23 & 18 & 5 & $3: 1$ & 0.13 & 0.72 \\
\hline K33-81 x K210-35 & 23 & 23 & 0 & --- & --- & --- \\
\hline K33-81 x A90-132 & 15 & 15 & 0 & --- & -.- & --- \\
\hline B $69-85 \times \mathrm{K} 210-35$ & 10 & 10 & 0 & --- & -- & -- \\
\hline $\mathrm{K} 60-31 \times \mathrm{K} 31-110$ & 7 & 7 & 0 & --- & $\ldots$ & --- \\
\hline K210-35 x K104-98 & 24 & 24 & 0 & -- & --- & --- \\
\hline $\mathrm{K} 210-35 \times \mathrm{K} 50-65$ & 53 & 53 & 0 & --- & --- & --- \\
\hline $\mathrm{K} 210-35 \times \mathrm{K} 51-71$ & 140 & 138 & 2 & --- & --- & --- \\
\hline
\end{tabular}

